\title{
Seize opportunities and jointly advance China-EU economic and trade relations
}

\author{
Xiang Xia ${ }^{1}$
}

Received: 26 April 2021 / Revised: 26 April 2021 / Accepted: 26 May 2021 /

Published online: 9 June 2021

(c) The Author(s), under exclusive licence to Springer-Verlag GmbH Germany, part of Springer Nature 2021

\begin{abstract}
After 35 rounds of talks over the past seven years, the negotiations on the ChinaEU Comprehensive Agreement on Investment (CAI) passed the finishing line at the end of 2020, a timely gift for the 45th anniversary of the establishment of ChinaEU diplomatic ties. As a most comprehensive and significant economic and trade agreement between China and the EU, CAI marks a highly relevant step to meet the expectations of different sectors and should be cherished by both sides.
\end{abstract}

\section{An agreement based on rules and up to high standards}

No doubt, CAI is as ambitious as expected.

Aligned with state-of-the-art international economic and trade rules, CAI commits to a foreign investment management model based on pre-establishment national treatment and a negative list. China has for the first time committed to a negative list approach to all sectors, services, and non-services alike, including a number of sectors with high values such as finance, cloud services, new energy vehicles, and private healthcare. The EU commits to high-level market access for Chinese investors as well.

CAI formulates balanced and comprehensive rules on the level playing field, covering a wide range of important issues such as stated-owned enterprises, transparency of subsidies, transfer of technology, standard-setting, and financial regulation. The rules, which apply to both parties, could make the business environment more predictable and offer investors a greater sense of certainty.

CAI sets out specific rules on investment-related environment and labor issues, reflecting both parties' commitments to new development philosophies and the relevant international rules. The agreement aims to encourage investments that promote the UN SDGs, and strike the right balance between investment promotion and

Xiang Xia

xiaxiang@mofcom.gov.cn

1 Mission of the People's Republic of China to the European Union, Brussels, Belgium 
protection of environment and labor rights. Both parties are firmly committed to implementing the Paris Agreement to tackle climate change.

\section{An agreement that benefits all}

The CAI will produce positive effects in many aspects.

Firstly, CAI will further eliminate barriers in two-way investment and make China-EU economic and trade relations more balanced. The agreement could help foster closer links between the Chinese and EU markets and increase the proportion of investment in the overall China-EU economic ties, which is relatively low at the moment. In China, the annual sales of new energy vehicles exceed one million units. The financial sector takes up over $8 \%$ of the total GDP. The output of private healthcare is about US\$60 billion. Cloud services are valued more than US\$10 billion. All these sectors will be further opened to EU investors and could become new investment niches for EU companies. Chinese investors in the EU will enjoy stronger institutional safeguards as well.

Secondly, CAI is of great significance to growth and post-COVID-19 recovery. This high-standard agreement represents a concrete step taken by China and the EU, as two major economies and major forces for stability, to build a rules-based and open world economy, and conveys a positive message of upholding multilateralism and supporting economic globalization. Thus, the agreement could help keep global industrial and supply chains stable and unimpeded and add positive energy to global economic recovery. The huge Chinese market with 1.4 billion consumers is embracing new opportunities for high-quality development. The EU is working on its recovery program featuring green and digital transformation. CAI could open up a broader horizon for China-EU cooperation across the board.

Thirdly, CAI will inject new impetus to China's reform and opening up. Over the past 40-plus years of reform and opening up, China has lifted 800 million people out of poverty, and has come a long way in economic and social development. Reform and opening up is the shared commitment of the 1.4 billion Chinese people. CAI defines obligations for high-level opening up and offers a new driving force for China's shift from factors-based opening to institutional opening. This is the solemn commitment made by China to the EU and the world in the form of an international treaty. China's development may not be free of problems and difficulties. Yet we keep moving in the right direction step by step, from reform and opening up to building a socialist market economy, from joining the WTO to concluding the CAI. Small actions would accrue to a big difference. We firmly believe that opportunities arise from challenges and that pressure propels us to go forward. A more open and inclusive China is not only a good thing for itself, but also for the EU and the world.

\section{An agreement that addresses divergences and builds consensus}

CAI is indeed not the panacea to all the issues. However, it is a crucial step forward. 
Since the CAI negotiations were concluded as announced, there has been debate within the EU. Some say that the agreement should cover more issues and others say that the agreement should be more ambitious. The EU friends are primarily concerned about the timing and enforceability of the agreement, and provisions on labor protection and level playing field. I would like to reiterate that concluding the CAI negotiations was an objective set by Chinese and EU leaders in 2019, not an expediency. The agreement sets out a dispute settlement mechanism and an investment committee to ensure effective implementation. We hope to build a rules-based economic and trade relationship between China and the EU.

The EU is reviewing its new trade policy, which emphasizes market access, level playing field, and sustainable development. The conclusion of CAI demonstrates that the agreement in essence is a mutually beneficial and win-win move, and there are no fundamental differences in the direction of our policies. China and the EU should work together to draw the blueprint for the future of our economic and trade relations.

As the world is experiencing profound changes, it is imperative to keep China-EU economic and trade relations abreast with the times and seek new breakthroughs. In 2020, China became the EU's largest trading partner in goods. Only by making the pie bigger together can we bring our economic and trade relations to a new level.

As a most comprehensive and significant economic and trade agreement between China and the EU, CAI marks a highly relevant step to meet the expectations of different sectors and should be cherished by both sides. Despite China-EU relations encountered some challenges recently, China is still firmly convinced that mutual benefit and win-win cooperation remain the keynote of China-EU relations. To enhance mutual understanding, there is no alternative to engagement and dialogue. Equal-footed consultation in a spirit of mutual respect and mutual accommodation is the only viable choice to address divergences and challenges. With a shared commitment to partnership and cooperation, China and the EU could get much done in terms of addressing global challenges and achieving inclusive development.

Publisher's note Springer Nature remains neutral with regard to jurisdictional claims in published maps and institutional affiliations. 